\title{
Anna Sosnowska* \\ Dynamics of mid-channel bars in the Middle Vistula River in response to ferry crossing abutment construction
}

https://doi.org/10.1515/geo-2020-0049

received July 24, 2019; accepted November 15, 2019

Abstract: The investigation focused on the non-migrating mid-channel bars that emerged in the river channel as a consequence of river engineering. A reach of around $280 \mathrm{~km}$ of Middle Vistula River (Poland) was taken into account as the study site. The most vivid examples of the river engineering works potentially influencing the river channel are the ferry crossings. Along the Middle Vistula River reach, there are 17 ferry crossings that were constructed from 1970s to 1990s. A cartographic analysis was carried out to determine the influence of the ferry crossing construction over the river channel. It was performed on the basis of aerial photographs (traditional aerial photography and UAV photography). In 3 out of 17 potential localizations, the emergence of large non-migrating mid-channel bars was observed. A study of cartographic materials (from 1950s to 2000s) allowed determination of the dynamics of those bars, including time of emergence and the changes of their size.

Keywords: channel bars, river engineering, Middle Vistula River, sediment transport

\section{Introduction}

Channel bars in alluvial rivers are integral structures in the river channels [1]. The reasons for non-migrating mid-channel bar development can be either channel planform variations or changes in channel width [2,3]. The nature of those processes can be dual: natural or activated. Irrespective of the reasons for mid-channel bar

\footnotetext{
* Corresponding author: Anna Sosnowska, Department of Water Engineering and Hydraulics, Faculty of Building Services, Hydro and Environmental Engineering, Warsaw University of Technology, ul. Nowowiejska 20, 00-653 Warszawa, Poland, e-mail: anna.sosnowska@pw.edu.pl
}

formation, the conditions in which they are formed are always similar. The emergence of bars in the river channel is always connected to high water flows which are characterized by high transporting potential. Not without a significance is the geological aspect of the river valleys. Valleys of rivers flowing in lowlands are composed of deep erosional base which is filled with alluvial deposits. Without such geological structure, the river would not have the possibility to adapt and reshape its channel in response to the flow dynamics [4].

The process of mid-channel bar creation itself in the river channel was described by many authors. In braided rivers, where different types of bars are ubiquitous, this process can be generalized into three steps. First, at the junction of two channels, a scour hole develops due to high flow velocity and flow turbulence in the central part of the joint channel. Then, the deposition of bed material begins downstream the scour hole, which is considered as bar growth. Finally, the size of the deposited bar is big enough to direct the flow into adjacent banks. This provokes bank erosion and flow divergence and results in creating two separate channels again [5].

Apart from flow dynamics, vegetation is the factor that is strongly connected to the stability of bars and islands, especially in braided rivers [6]. Experiments [7] show that the existence of riparian vegetation reduces the number of active channels in a braided river and reduces the mobility of the channel, simultaneously strengthening the banks and bars in the channel.

As long as the morphological changes in the channel occur naturally in small rivers, they are usually of low importance. It is different in the case of big rivers that are widely used in many ways (e.g., transportation, water supply and energy plants). Any change in the river morphology may affect the exploit of the river. In this case, Vistula River, the biggest river in Poland, is discussed. Thus, any morphological changes are very important and need close observation.

The main objective of the present work is to describe the trends and the rate of the mid-channel bar formation 
due to the human impacted contraction of the river channel. The most vivid example of river engineering works that lead to sharp narrowing of the main channel is the construction of ferry crossings.

\section{Study site}

Vistula River is the longest and the biggest river in Poland. It has a length of over $1,000 \mathrm{~km}$ and a catchment area of almost 2,00,000 sq km. The whole river, due to hydrological conditions, is divided into the following three reaches: upper, middle and lower one. The focus is on the Middle Vistula River reach, which stretches from the mouth of San River (297.7 km of Vistula) to the mouth of Narew River (550.5 km of Vistula). The floodplain valley width varied along the Middle Vistula and is from 1.1 to $14 \mathrm{~km}$. The whole river reach is embanked, regulated and equipped with technical devices, such as water intakes, gauging stations, bridges and ferry crossings [8]. However, the last large-scale engineering works in the river channel were conducted in 1960s and 1970s of the last century. Since that time, there were only necessary renovations carried out of local coverage. Thus, the technical condition of the river engineering constructions is rather moderate or even weak.

Middle Vistula River is a big sandy braided river, with a predominance of sediments being transported as bedload. Even though it does not look like a typical braided river with multiple anabranches, it fulfils majority of the braided river's characteristics, such as high stream power, non-uniform flow, unconsolidated flow and non-uniform bed topography [5]. Average yearly river load for Vistula River in Warsaw (for 1948/ 1949-1960/1961) was calculated to be around 0.5 million cu m. [9]. This value was then confirmed in calculations for 2006-2007 [10].

The origin of the Vistula River is connected to the glaciations that took place in the Quaternary and the period of great climatic changes between Pleistocene and Holocene. Those changes resulted in the gradual development of meandering river channel as a consequence of equalization of discharges. Vistula River has maintained its meandering character up to seventeenth century. Since then, as a result of human activity, the hydrological conditions have changed to more extreme flows leading to the formation of braided river pattern by the Vistula. [11]

The contemporary braided channel of the Middle Vistula River is confined by cohesive deposits. Their existence in the river channel, as revealed by the field studies, takes the shape of elevations made of nonerodible deposits. Those forms are exposed in the channel bottom during floods and prevent the river from eroding deeply along its whole length. The morphology of these elevations affects the position of the flood main stream and the localization of erosional processes [4].

In the preliminary studies, the whole Middle Vistula River reach, which is about $280 \mathrm{~km}$ long, was investigated. Along this river section, 17 ferry crossings were identified, which could possibly have strong impact on the local river morphology. At each crossing localization, the river fragment of about $1 \mathrm{~km}$ upstream and $3 \mathrm{~km}$ downstream was considered. Due to the restricted availability of the archival aerial photographs, 13 ferry crossings were finally analysed. In only three localizations, the emergence of large non-migrating mid-channel bars was observed. According to the terminology used by Smith [12], all of the identified bars were unit bars of longitudinal shape.

Those localizations (Figure 1) are as follows:

- Gassy-Karczew crossing (488 km of Vistula River; Figure 2),

- Brzumin-Piwonin crossing (469 km of Vistula River; Figure 3) and

- Latków-Ostrów crossing (440 km of Vistula River; Figure 4).

Those three localizations were analysed deeply in the next step of the study. First, some geometry measurements were made. They include the width of the ferry crossing, the width of the main river channel and the width of the flood channel. The width of the ferry crossing is the distance between two abutments of the crossing. The main river channel width is the distance between the right and left bank of the river, just upstream the ferry crossing. The flood channel width is the distance between the embankments, which was measured about $5 B$ in length upstream the crossing (while $B$ is the main channel width). Then, based on those values two concentration coefficients (for main channel and for flood channel) were calculated to characterize the cross-sections on the Vistula River at the ferry crossings. Geometry of the river channel and the ferry crossings is described subsequently.

\subsection{Gassy-Karczew crossing}

The ferry crossing between Gassy and Karczew is localized in $488 \mathrm{~km}$ of Vistula River. It was commissioned in 1981, but 


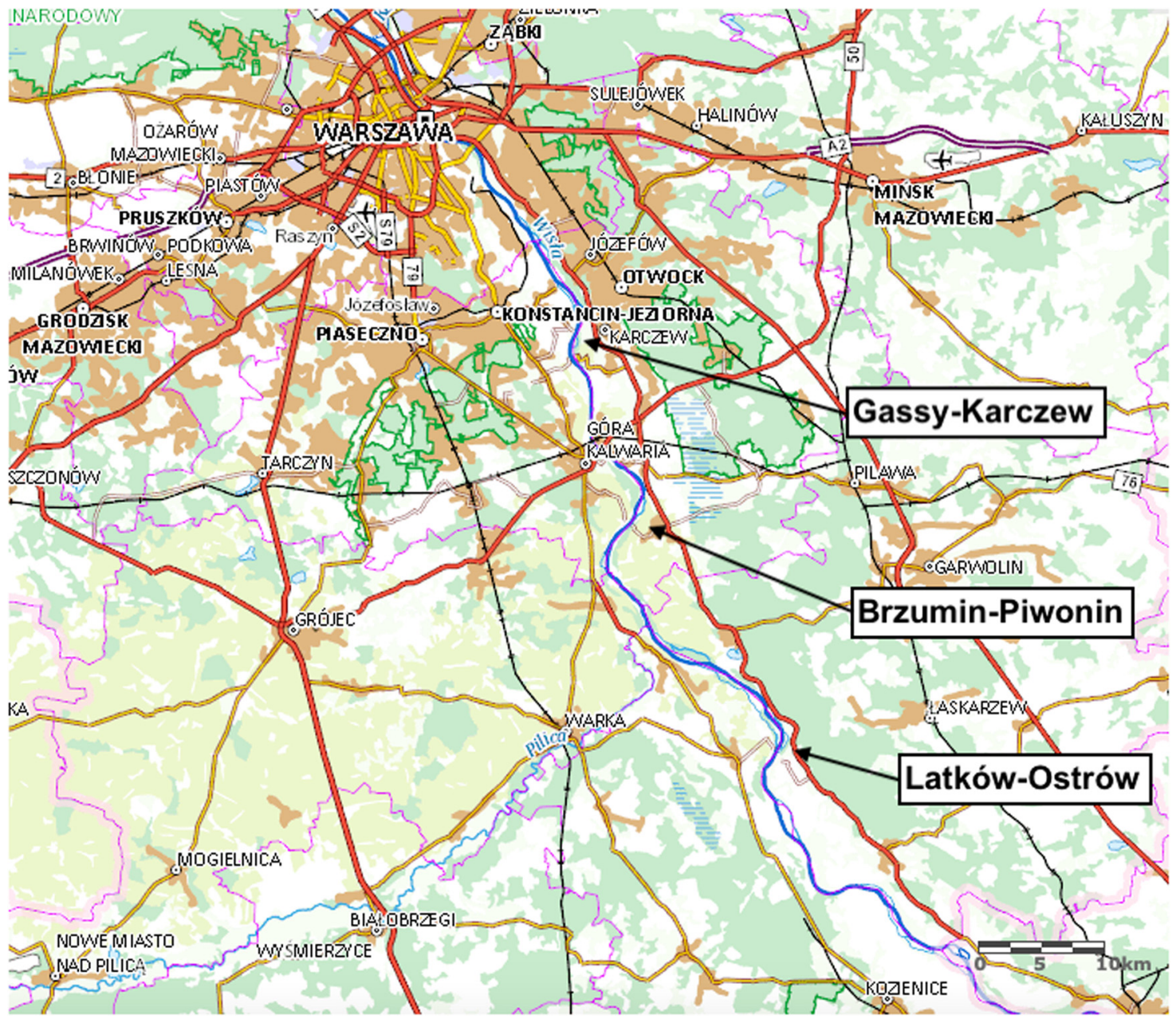

Figure 1: Localization of the ferry crossing constructions investigated in the study, map source [13].

the construction is visible in the river channel on the photographs from 1979. The ferryboat operates from April to November as long as the hydraulic parameters of the river allow for that. The structure consists of two abutments protruding from the banks of the river channel. The crossing is placed in the central part of the channel's cross-section. Considering the planform of the river, it is localized at the run (inflection) between two bends. The width of the crossing is around $190 \mathrm{~m}$, while the distance between the bank upstream and downstream the crossing is about $460 \mathrm{~m}$. The channel contraction ratio at the crossing is $41 \%$. The flood channel width is around $980 \mathrm{~m}$ and that gives the flood concentration coefficient of $17 \%$.

\subsection{Brzumin-Piwonin crossing}

The Brzumin-Piwonin ferry crossing is localized in $469 \mathrm{~km}$ of Vistula River. The structure was commissioned in 1983. There is no ferryboat operating regularly here. Two protruding abutments create a narrowing that is positioned centrally in the cross-section. However, at the right bank of the river channel there is a stable point bar that was formed in the past and now creates a new shoreline. This gives an impression that the crossing is positioned at the right bank. The crossing is localized at the run. The width of the narrowed channel at the crossing is $210 \mathrm{~m}$. The width of the river channel upstream and downstream is around $280 \mathrm{~m}$. The contraction ratio is $75 \%$. The width of the flood channel is about $1,100 \mathrm{~m}$. The flood concentration ratio is $19 \%$.

\subsection{Latków-Ostrów crossing}

The crossing connecting Latków and Ostrów is localized in $440 \mathrm{~km}$ of Vistula River. It was commissioned in 1992. The ferryboat operates periodically during favourable 


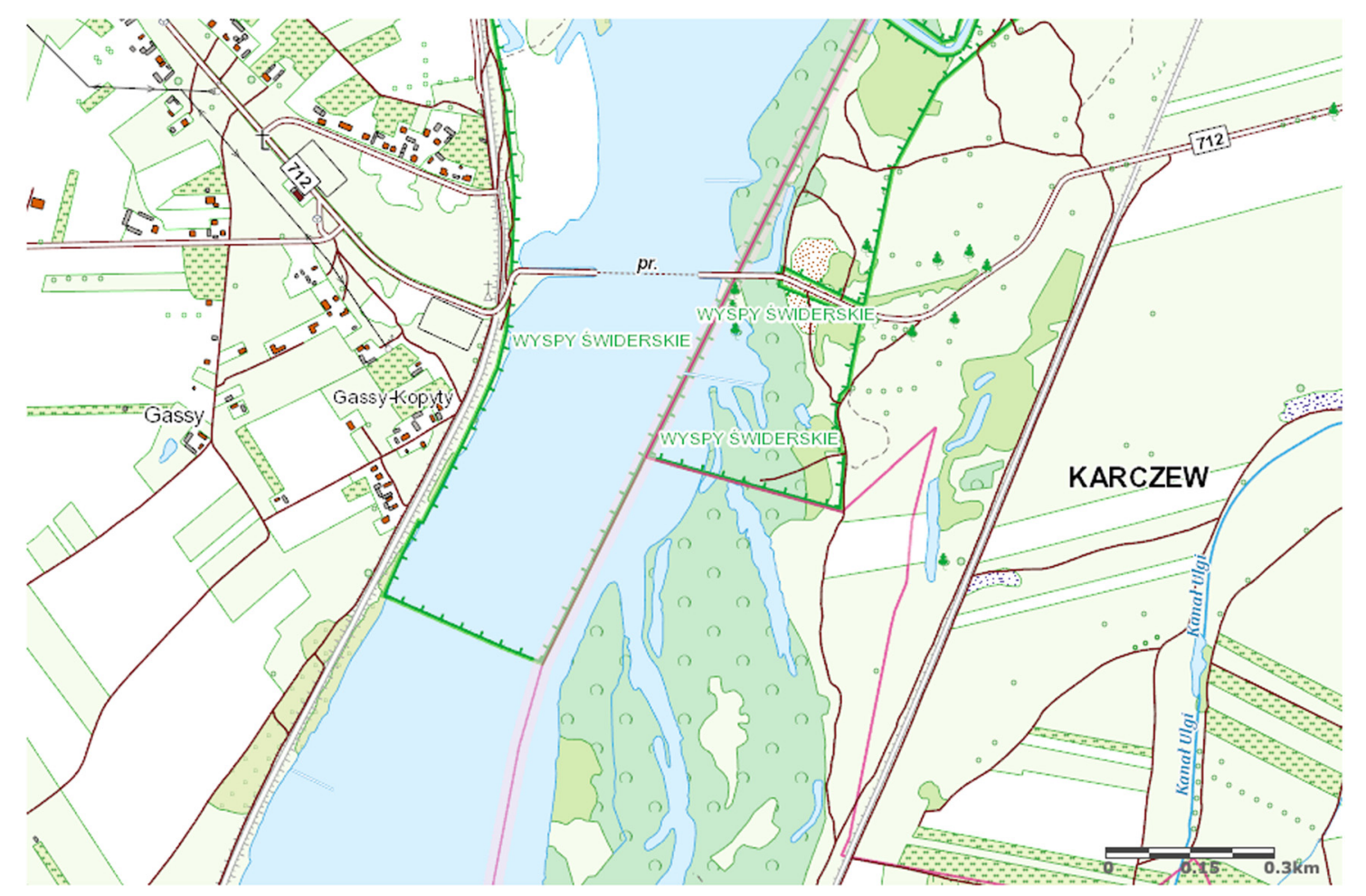

Figure 2: Localization of the Gassy-Karczew ferry crossing, map source [13].

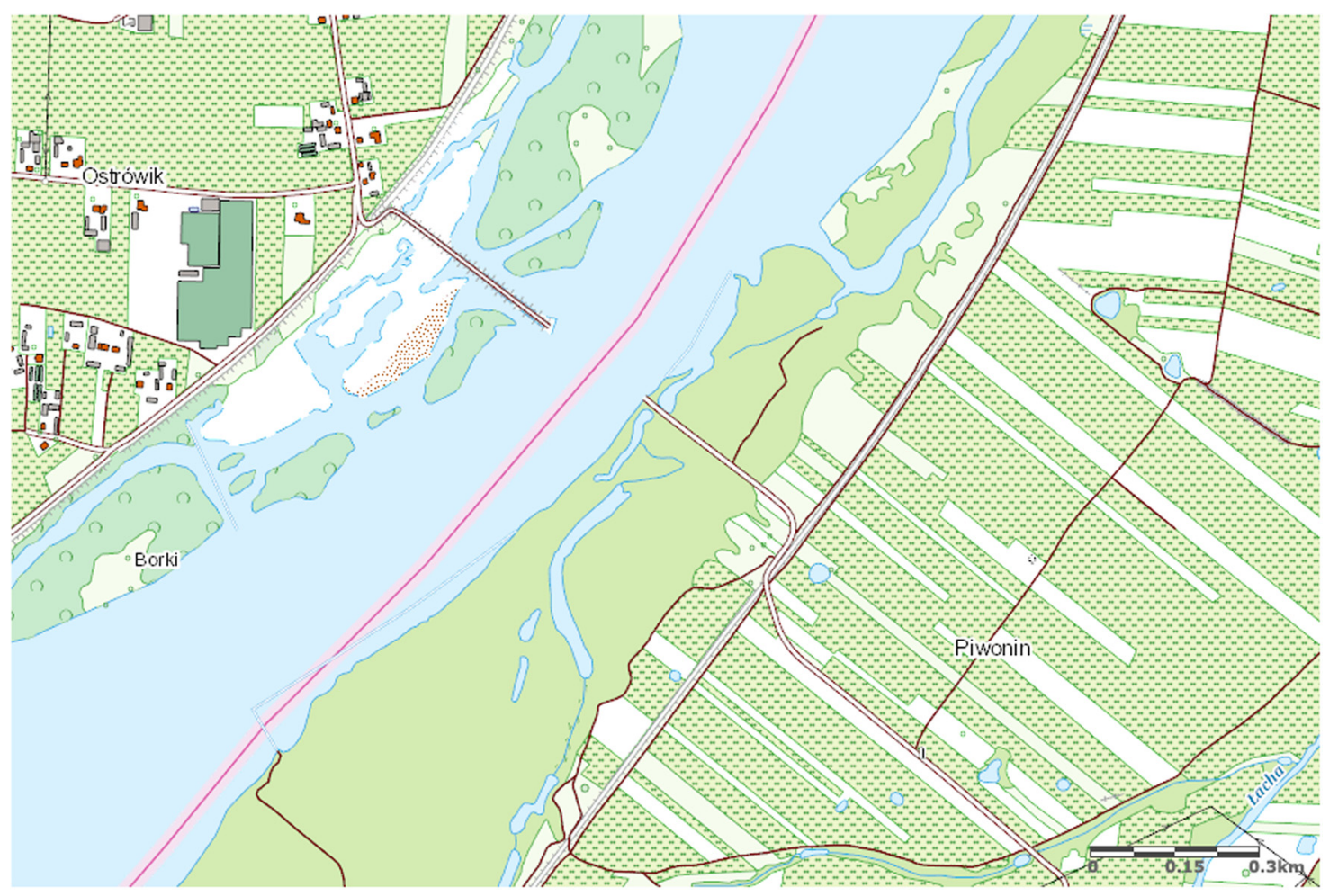

Figure 3: Localization of the Brzumin-Piwonin ferry crossing, map source [13].

river conditions. The structure is composed of one abutment protruding from the right bank of the river channel. At the left bank, there is only some bank reinforcement. The crossing is about $170 \mathrm{~m}$ wide, while 


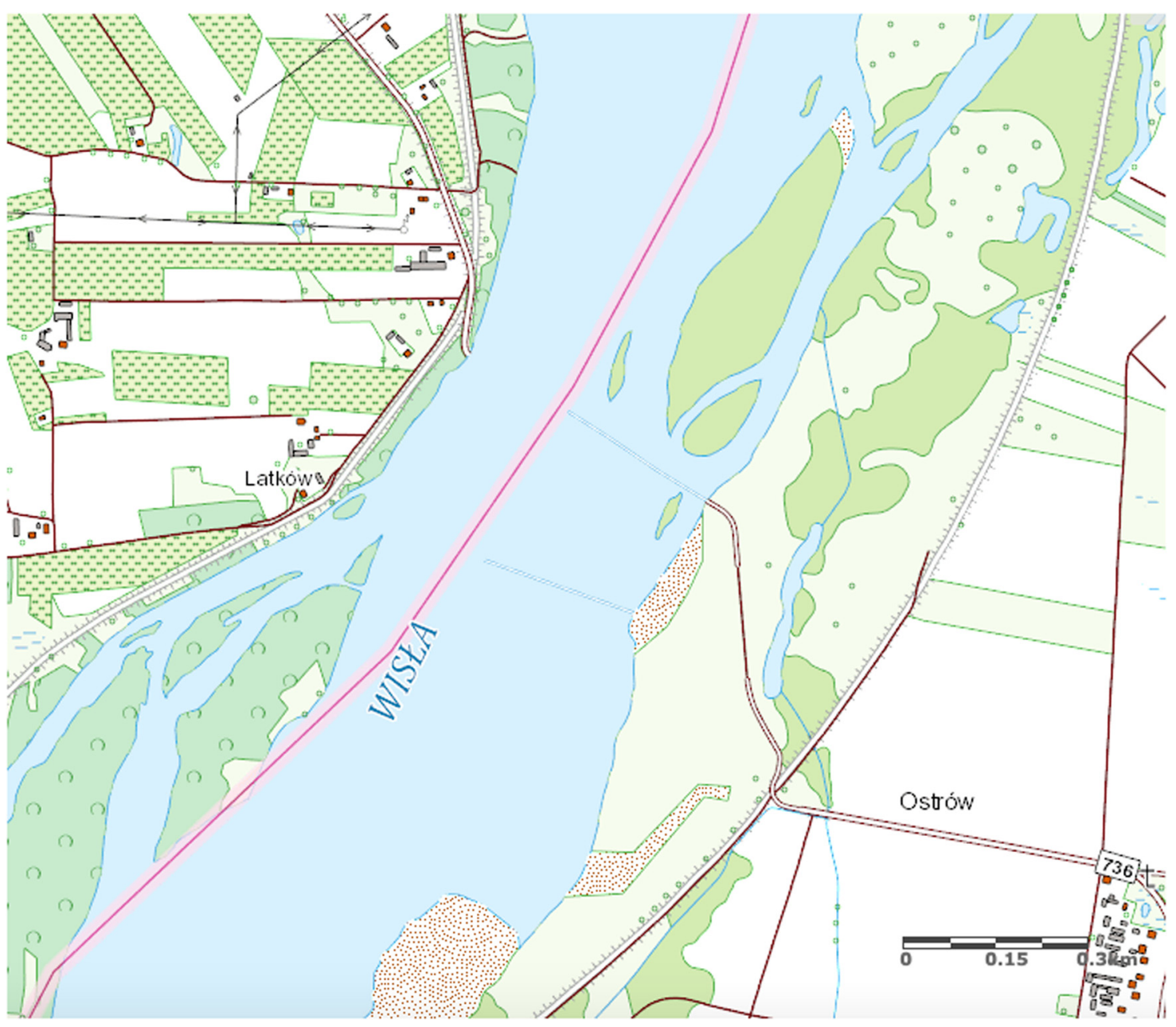

Figure 4: Localization of the Latków-Ostrów ferry crossing, map source [13].

the cross-section of the river channel is around $460 \mathrm{~m}$. That gives the contraction ratio of $37 \%$. The flood channel width is around $980 \mathrm{~m}$, so the flood concentration coefficient is $19 \%$.

The summary of the most important data concerning those three ferry crossings is presented in Table 1.

\section{Methods}

The method of comparison of cartographic materials used in this work is common and suitable for river morphology evaluation [14-16]. The investigation of the changes in the river channel was based on the analysis of the aerial photographs of the river that were taken in different time periods. Distinct series of photographs come from years: 1959, 1979, 1981, 1984, 1997, 2000s (2003-2007) and 2018 (only for Gassy crossing). The hydrological conditions corresponding to the distinct series are similar. All the photographs were taken for flow values between mean and low flow values. This is particularly important for morphological analysis, as all the structures in the channel are clearly visible during low stages. Example hydrological data (for Warszawa-Nadwilanówka gauging station) are presented in Table 2 together with the corresponding values of mean and low flow.

The analysis of the photographs was conducted using ArcGIS software by georeferencing the pictures coming from distinct series. Based on the photographs some morphological measures were compared for each series of photographs. Those were as follows:

- Course of the shorelines.

- Contours of the mid-channel bars.

- Area of the mid-channel bars.

The effect of the photograph comparison for all three localizations is visible in Figures 5-7. 
Table 1: Description of the ferry crossings

\begin{tabular}{|c|c|c|c|c|c|c|c|}
\hline $\begin{array}{l}\text { Ferry } \\
\text { crossing }\end{array}$ & $\begin{array}{l}\text { Localization in } \\
\text { cross section }\end{array}$ & $\begin{array}{l}\text { Localization in } \\
\text { planform }\end{array}$ & $\begin{array}{l}\text { Width of the } \\
\text { crossing }(m)\end{array}$ & $\begin{array}{l}\text { Width of river } \\
\text { channel }(\mathbf{m})\end{array}$ & $\begin{array}{l}\text { Width of flood } \\
\text { channel }(m)\end{array}$ & $\begin{array}{l}\text { Contraction } \\
\text { ratio (\%) }\end{array}$ & $\begin{array}{l}\text { Flood } \\
\text { concentration } \\
\text { ratio }(\%)\end{array}$ \\
\hline Gassy & Central & Run & 190 & 460 & 980 & 41 & 17 \\
\hline Brzumin & $\begin{array}{l}\text { Central } \\
\text { (right bank) }\end{array}$ & Run & 210 & 280 & 1,100 & 75 & 19 \\
\hline Latków & Left bank & Run & 170 & 460 & 980 & 37 & 19 \\
\hline
\end{tabular}

Table 2: Information about aerial photographs' series [17]

\begin{tabular}{|c|c|c|c|c|c|}
\hline Series & Date & Stage $(\mathrm{cm})$ & Flow (cu m per s) & Mean flow ${ }^{a}$ (cu m per s) & Low flow ${ }^{a}$ (cu m per s) \\
\hline 1959 & 13-Sep-1959 & $-{ }^{\mathrm{b}}$ & & $573( \pm 117)$ & $211( \pm 58)$ \\
\hline 1979 & 7-Oct-1979 & 127 & 338 & & \\
\hline 1981 & 27-Oct-1981 & 204 & 483 & & \\
\hline 1984 & 31-Oct-1984 & 143 & 373 & & \\
\hline 1997 & 8-Dec-1997 & 319 & 541 & & \\
\hline 2003 & 19-Sep-2003 & 192 & 193 & & \\
\hline 2018 & $13-0 c t-2018$ & & & & \\
\hline
\end{tabular}

${ }^{a}$ Values for Warszawa-Nadwilanówka gauging station for time period from 1951 to 1990 according to [17]. ${ }^{b}$ Gauging station non-existent.

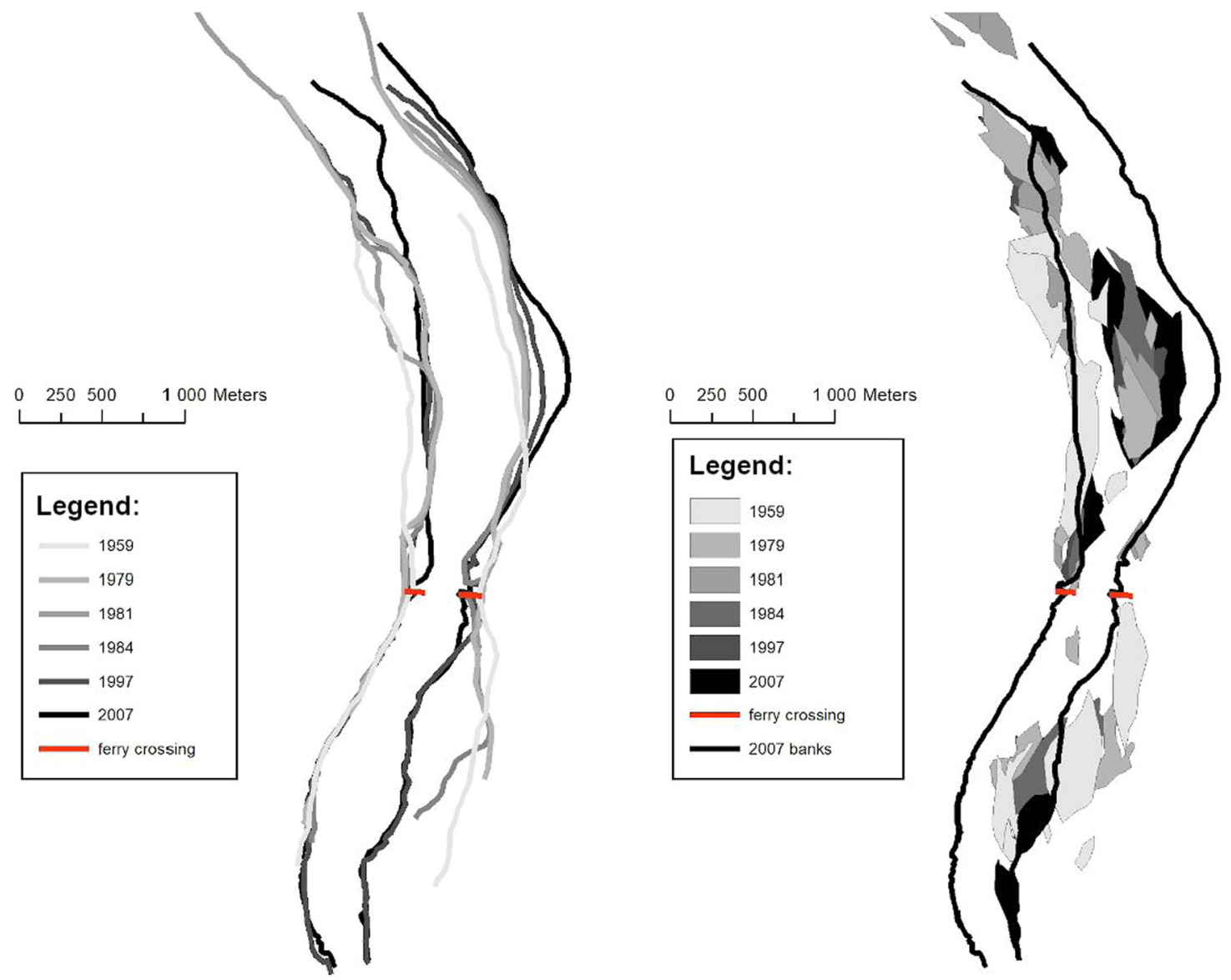

Figure 5: Changes in shorelines and mid-channel bars for Gassy-Karczew crossing. 


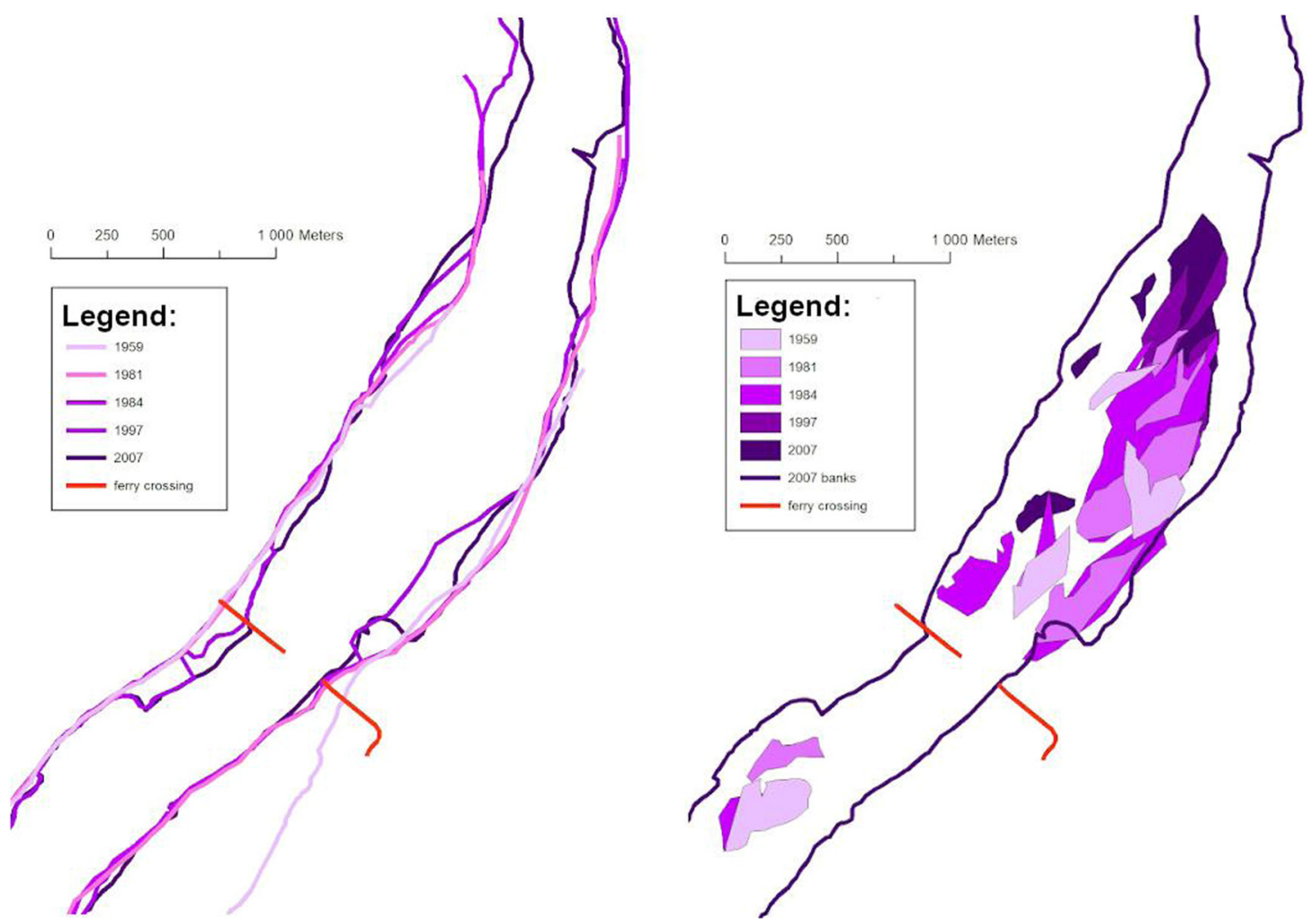

Figure 6: Changes in shorelines and mid-channel bars for Brzumin-Piwonin crossing.

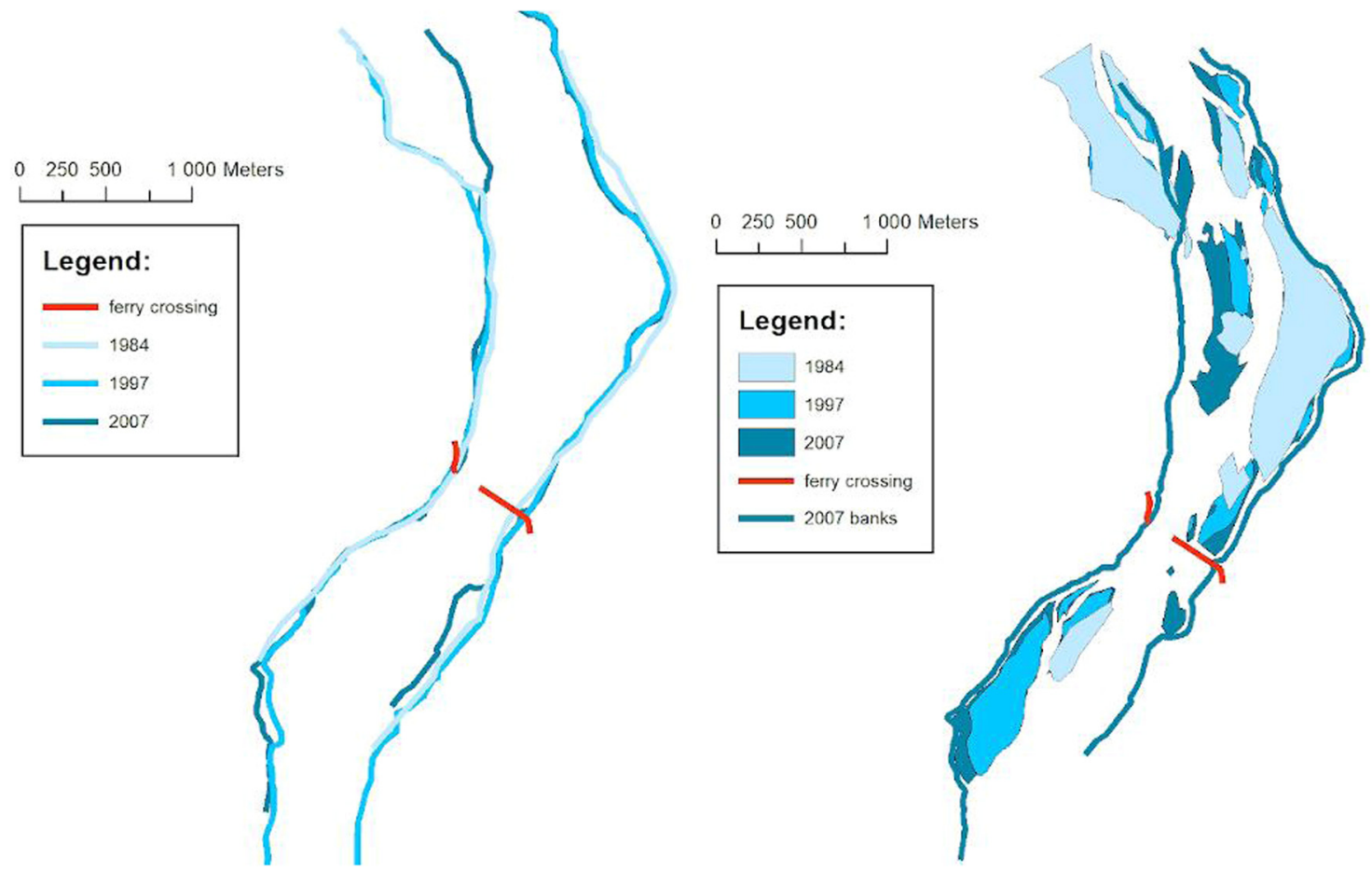

Figure 7: Changes in shorelines and mid-channel bars for Latków-0strów crossing. 


\section{Results}

In case of all three localizations, some changes in shorelines were observed. For Gassy crossing, the width of the channel has been slightly decreasing in time along the analysed fragment. There is only one exception, on the right bank along the bow downstream the crossing, the process of bank erosion was observed. As it was stated in [18], the right bank of the channel has moved around $270 \mathrm{~m}$ (from 1959 to 2003). In the second localization (Brzumin), slight changes in shorelines along the section are visible as well. The channel has been narrowed with the exception of the fragment along the mid-channel bar that has arose downstream the crossing. Along this bar, channel widening is visible. At both banks, the widening is of about $100-200 \mathrm{~m}$. In the case of Latków crossing, there are no significant changes in shoreline localization yet.

Considering the mid-channel bar development, in all three localizations the dimensions of the bars have increased in time (Figure 8 and Table 3).

The data presented in Figure 8 and Table 3 show that the character of the mid-channel bar development is different for Brzumin localization than for the Gassy and Latków localizations. For Brzumin crossing, the emergence of the bar was very quick with the rate of almost 60,000 sq m per year and since 1984 the size of the bar is quite stable, around 3,00,000 sq m. Midchannel bar in Gassy is the biggest (almost 7,00,000 sq $\mathrm{m})$, with the biggest pace of increase $(18,700 \mathrm{sq} \mathrm{m}$ per year). Mid-channel bar in Latków has emerged lately, but the rate of the bar development is quite high as well.

\section{Discussion/conclusion}

River engineering structures, such as ferry crossings, certainly have an impact on the river channel locally. In the case of ferry crossings in Gassy and Brzumin, significant changes in shorelines were noticed. Along the emerged mid-channel bars, widening of the river channel was observed. In all of the discussed cases, the area of the emerged mid-channel bars was increasing in time. The rate of the bar development was different for the crossings in Gassy and Latków than for the crossing in Brzumin. The former were rather uniform, while the bar in Brzumin has developed very quickly at the beginning and then became more or less steady.

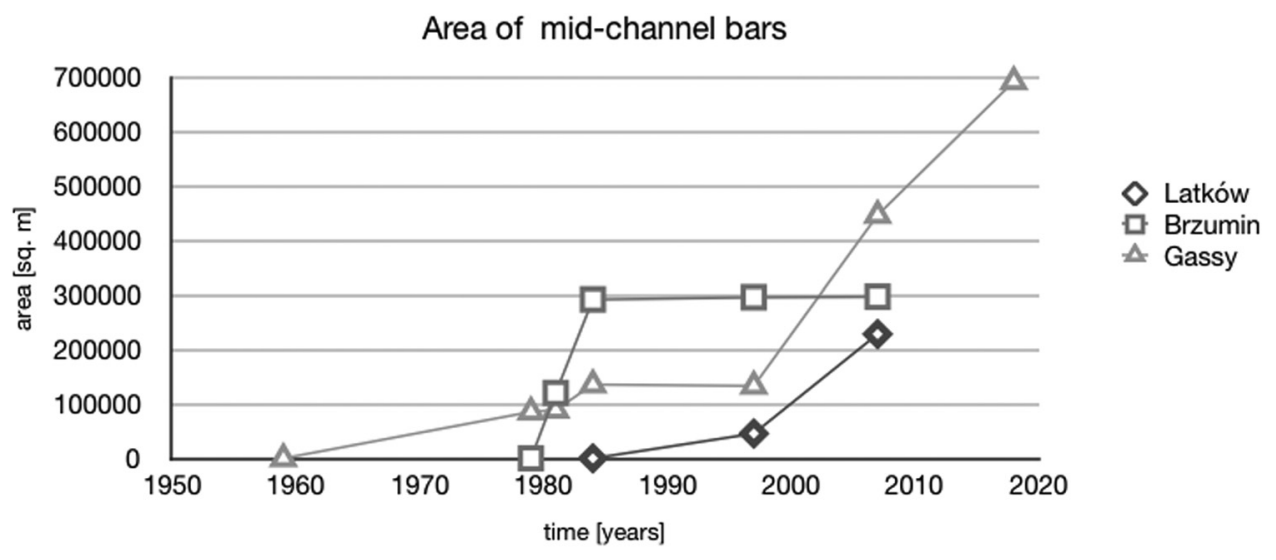

Figure 8: Area of mid-channel bars.

Table 3: Development of the mid-channel bars in all three localizations

\begin{tabular}{llrrrrrl}
\hline Ferry crossing & \multicolumn{6}{c}{ Area of the bar $(\mathbf{s q} \mathbf{~ m})$} & Mean rate of increase (sq m per year) \\
\cline { 2 - 7 } & $\mathbf{1 9 5 9}$ & \multicolumn{1}{c}{$\mathbf{1 9 8 1}$} & $\mathbf{1 9 8 4}$ & $\mathbf{1 9 9 7}$ & $\mathbf{2 0 0 3 - 2 0 0 7}$ & $\mathbf{2 0 1 8 - 2 0 1 9}$ & \\
\hline Gassy & 0 & 89,000 & $1,35,700$ & $1,33,200$ & $4,46,600$ & $6,92,400$ & 18,700 \\
Brzumin & 0 & $1,20,400$ & $2,91,900$ & $2,95,800$ & $2,96,900$ & & 12,400 \\
Latków & 0 & 0 & 0 & 45,600 & $2,28,500$ & & 15,200 \\
\hline
\end{tabular}


The main reason of the development of such big and stable mid-channel bars downstream the crossings is sharp narrowing of the river channel by the construction of ferry crossings. Not without the significance is the fact that the width of the narrowed channel at the crossing, in all three cases, is smaller than the regulatory width of the channel (about $220 \mathrm{~m}$ ) for Middle Vistula. Probably, if the crossings were constructed to fit the existing regulatory parameters, the mid-channel bars would not have been developed, as it was in the case of other ten ferry crossings along Middle Vistula that were analysed in preliminary studies.

Also, the geometry of the river channel at the crossing and of the ferry crossing itself is meaningful. The values of the concentration ratio for Gassy and Latków crossings are similar (around 40\%) and for Brzumin it is $75 \%$. The value of flood concentration ratio is similar for all three crossings and is from 17 to $19 \%$. Since the largest morphological changes of the river channel occur during floods, it is worth examining the values of those coefficients in other cases of the ferry crossings along Middle Vistula River.

The emergence of big mid-channel bars in described localizations is certainly a sign of some morphological processes occurring in the river channel. However, after stabilization of the bars by vegetation and in favourable hydrological conditions (low and mean discharges), the bars themselves can become obstacles for water flow, being simultaneously the factor influencing further morphological processes in the channel.

On the other hand, the stability of the river morphology at Middle Vistula River reach can be strongly connected to the specific geological structure of the channel zone. As it was stated in [19], sub-alluvial bedrock protrusions affect the direction of high-water flow and erosion in the channel zone. Non-erodible elevations of bedrocks in the river channel may create favourable localizations of the alluvia deposition. This may result in the emergence of stable midchannel bars directly at the bedrock protrusions.

Constantly increasing mid-channel bars will have the impact on the channel morphology as well as ecological and economical effects.

\section{References}

[1] Wang BY, Xu J. Dynamics of 30 large channel bars in the Lower Mississippi River in response to the river engineering from 1985 to 2015. Geomorphology. 2018;300:31-44.
[2] Wintenberger CL, Rodrigues S, Claude N, Juge P, Breheret J-G, Villar M. Dynamics of nonmigrating mid-channel bar and superimposed dunes in a sandy-gravelly river (Loire River, France). Geomorphology. 2015;248:185-204.

[3] Luchi R, Hooke JM, Zolezzi G, Bertoldi W. Width variations and mid-channel bar inception in meanders: River Bollin (UK). Geomorphology. 2010;119:1-8.

[4] Falkowski T. Alluvial bottom geology angered as a factor controlling channel flow along the Middle Vistula River, Poland. Geol Q. 2007;51:91-102.

[5] Ashworth PJ. Mid-channel bar growth and its relationship to local flow strength and direction. Earth Surf Process Landf. 1996;21:103-23.

[6] Gurnell A. Plants as river system engineers. Earth Surf Process Landf. 2014;39:4-25.

[7] Gran K, Paola C. Riparian vegetation controls on braided stream dynamics. Water Resour Res. 2001;37:3275-83.

[8] Wierzbicki J. Wisła Środkowa. In: Piskozub A. Wista: monografia rzeki. Warszawa: Wydawnictwa Komunikacji i Łączności; 1982.

[9] Skibiński J. Wleczenie rumowiska dennego przez Wisłę w rejonie Warszawy. Wiadomości Służby Hydrologicznej i Meteorologicznej. 1963;53:3-37.

[10] Kuźniar P. Zmiany pionowego układu zwierciadła wody oraz morfologii dna koryta Wisły Warszawskiej na odcinku od km 497 do km 527 w świetle materiatów archiwalnych i wyników pomiarów 2008 r. Warszawa: Politechnika Warszawska; 2009 (Unpublished material).

[11] Falkowska E, Falkowski T, Tatur A, Kałmykow-Piwińska A. Floodplain morphodynamics and distribution of trace elements in overbank deposits, Vistula River Valley Gorge near Solec nad Wistą. Acta Geol Pol. 2016;66:541-59.

[12] Smith ND. Sedimentology and bar formation in the Upper Kicking Horse River, a Braided Outwash Stream. J Geol. 1974;82:205-23.

[13] www.geoportal.gov.pl.

[14] Popek Z, Wasilewicz M. Variability of morphological conditions of the Vistula river channel in the section CzerwińskKępa Polska. Ann Wars Univ Life Sci-SGGW, Land Reclam. 2015;47:19-29.

[15] Forysiak J. The application of aerial photo analysis to reconstruct anabranching system of middle part of the Warta river valley. Landf Anal. 2010;13:13-18.

[16] Madaleno F, Fernandez-Yuste J. Meander dynamics in changing river corridor. Geomorphology. 2011;130:197-207.

[17] Fal B, Bogdanowicz E. Characteristic flow values of the main Polish rivers in the years 1951-1990: a new publication by the IMGW. Gospodarka Wodna. 1998;9:178-1789.

[18] Sosnowska A. Riverbed transformation as a result of a ferry crossing construction - case study. MATEC Web Conf. 2019;262:1-6.

[19] Bujakowski F, Falkowski T. Hydrogeological analysis supported by remote sensing methods as a tool for assessing the safety of embankments (case study from Vistula River Valley, Poland). Water. 2019;11:266. 